\title{
Sustaining Biological and Cultural Diversity
}

Geographic Indications and Traditional Mezcal Production in Jalisco, Mexico

Maintenir la diversité biologique et culturelle : indications géographiques et production traditionnelle du mezcal à Jalisco, Mexique

\section{Ana G. Valenzuela Zapata et Marie Sarita Gaytán}

\section{(2) OpenEdition}

\section{Journals}

Édition électronique

URL : http://journals.openedition.org/ethnoecologie/990

DOI : 10.4000/ethnoecologie.990

ISSN : 2267-2419

Éditeur

Laboratoire Eco-anthropologie et Ethnobiologie

\section{Référence électronique}

Ana G. Valenzuela Zapata et Marie Sarita Gaytán, « Sustaining Biological and Cultural Diversity », Revue d'ethnoécologie [En ligne], 2 | 2012, mis en ligne le 06 juillet 2016, consulté le 19 avril 2019. URL : http://journals.openedition.org/ethnoecologie/990 ; DOI : 10.4000/ethnoecologie.990

\section{Ce document a été généré automatiquement le 19 avril 2019.}

Revue d'ethnoécologie est mis à disposition selon les termes de la licence Creative Commons Attribution - Pas d'Utilisation Commerciale - Pas de Modification 4.0 International. 


\section{Sustaining Biological and Cultural Diversity}

Geographic Indications and Traditional Mezcal Production in Jalisco, Mexico

Maintenir la diversité biologique et culturelle : indications géographiques et production traditionnelle du mezcal à Jalisco, Mexique

Ana G. Valenzuela Zapata et Marie Sarita Gaytán

\section{Introduction}

1 In the last decade, researchers have addressed issues regarding the biological conservation of agaves and the use of traditional knowledge in relation to mezcal production (Valenzuela-Zapata and Nabhan 2004). The Agave genus is well represented in Mexico, numbering 150 species of a total of 200 species (García-Mendoza 2002). About $20 \%$ of the species (42) are used to produce mezcal in 26 different states throughout the republic (Colunga et al. 2007). The name "mezcal" encompasses a broad category of distilled agave drinks. Additionally (and confusingly), "mezcal" is the name of a specific distilled agave drink that is protected by Denomination of Origin (DO) legislation and is also a term that Mexicans colloquially use to refer to agave. Recent academic work on biodiversity, in addition to international efforts by neo-localist movements like Slow Food, have prompted renewed interest in the classification of diverse native ancient crops, such as agave, and their products, including mezcals. This heightened awareness is likewise fuelled by the tequila industry's increased presence and domination within the distilled agave drink market in the western Mexican state of Jalisco. Here, we add to these discussions by shedding much needed light on artisanal mezcal production and tracking the effects of industrialization on human tradition.

2 In this article, we ask: What agave species are currently used by both large and small scale manufacturers of tequila, raicilla, and mezcal in the state of Jalisco? What 
conditions enable the incorporation of more species and native landraces? We answer these questions by identifying the concepts, trends, regulations, and distinctive systems pertaining to agricultural biodiversity and human tradition. In addition to qualitative methods, we combine bibliographic material from scholarly sources. Therefore, our analysis is drawn from a combination of fieldwork conducted in mezcal-producing regions with artisanal manufacturers and a review of previous literature.

\section{Methods}

3 Fieldwork was carried out intensively by the first author between 2006 and 2008 and consisted of visits to taverns in regions where several different types of mezcal drinks are produced. Both individual and focus group interviews were conducted with traditional distillers. Interview questions were open-ended and centered on brand history and the distillation process. During on-site plantation visits, data, including botanical identifications (based on the work of Gentry 1982), were collected in addition to interviews with growers that focused on raw material use and harvesting procedures. Photographs were also taken to document the production process and to identify agave raw materials. Visits to tequila factories were also conducted, but no botanical data was collected during these trips because manufacturers are required by law to use only one type of agave (Agave tequilana Weber). In summary, field visits were carried out at 3 tequila distilleries and 10 mezcal and raicilla taverns.

Our findings are presented in three sections. First, we classify various mezcal producers on a scale ranging from artisanal production to industrial production. Second, we discuss the conservation of species biodiversity and the mixed-race agaves in each group of producers. In addition, we consider these efforts in light of Mexican DO regulations. Finally, we conclude by transitioning to a discussion of the socio-economic and cultural effects associated with these phenomena, especially in relation to the fluctuating prices of blue agave, the raw material used in the production of tequila.

\section{Cultural and Industrial Context}

In Mexico, agave is widely known as '"mezcal' (from the Nahuatl 'metl' = Agave and 'ixcali' = cooked or baked)" (Colunga García-Marín and Zizumbo-Villarreal 2007: 1653-1654). Agave inflorescence (quiotes) and agave hearts (stems and leaves basis : piñas) have been used as a food source for 9,000 years in Meso-America (Bruman 2000). Other agave materials, such as its leaves, were used for building homes and making clothing. For thousands of years, indigenous people throughout Mexico drank fermented agave beverages. The distillation of agave likely began in the seventeenth century with the introduction of "Filipino" stills (Bruman 2000). More recent findings by Zizumbo et al. (2009) suggest that distillation could have taken place in the state of Colima centuries before the arrival of the Spanish. In 1710 Pedro de Tagle,${ }^{1}$ a member of the Spanish elite, opened a mezcal factory in the Tequila-Amatitán Valley of Jalisco (Luna 1991). By the nineteenth century, several haciendas were producing what was known as vino mezcal de Tequila (mezcal wine from Tequila) for domestic consumption. Throughout the twentieth century, and as the international export market evolved, mezcal from the TequilaAmatitán Valley became known as "tequila” (Gaytán 2008). 
The formalization of the mezcal market led to the introduction of more industrialized methods of production. Increased levels of output and the overexpansion of blue agave plantations (used in the production of tequila) in the twentieth and the early twenty-first centuries have resulted in the diminished diversity of agave varieties or landraces (Valenzuela-Zapata and Nabhan 2004). Applying an ethnobotanical approach, Zizumbo et al. (2008) built upon Bruman's (2000) hypothesis that combined archaeological evidence with research on genetic diversity. Specifically, their findings emphasize the importance of Jalisco as a region with abundant evidence of antiquity crop production and a variety of native Agave angustifolia Haworth and A. rhodacantha Trelease.

7 Research documenting the origin of mezcal drinks sheds light on the diversity of agave in the region and its centrality in the lives of indigenous people. While tequila is the most famous of all distilled agave drinks, within the state of Jalisco, there is a long history of local and micro-regional mezcal production. Ironically, in recent years, tequila's popularity, and its increasing economic importance, has overshadowed efforts to preserve many other native mezcals. Thus, dozens of mezcals are not recognized under Do protective measures.

\section{Names, Norms, and Regulations}

Established in 1974 by the Mexican government, the Denomination of Origin (DO) for tequila outlines a set of specific production guidelines and states that tequila may only be made in five Mexican states (Bowen and Valenzuela 2009). DO products such as tequila and mescal are classified in the Official Mexican Norm (NOM) (Tequila, Secretaría de Economía 2006a; Mezcal: Secretaría de Economía 2009); distilled agave drinks are classified in the Emergent Norm or Norma Oficial Mexicana de Emergencia (Secretaría de Economía 2006b).

Within the DO guidelines for tequila and mezcal there is a clause which allows for the use of sugars from outside sources, such as high fructose corn syrup from the United States (Bowen and Gaytán 2012). Specifically, tequila producers may combine $49 \%$ outside sugar sources and mezcal producers may combine $20 \%$ outside sugars. Only those products that are made with $100 \%$ agave are considered authentic or traditionally crafted. While nearly all distilled agave drinks are considered mezcal, most are made from $100 \%$ agave of various species. The specific conditions of savoir-faire are not specified in the official guidelines outlined in the Mexican standards. As a result of lax regulations regarding the use of modern or traditional production techniques, artisanal tequila, mezcal, or other distilled agave spirits are not protected by these measures. In the words of Bowen (2008: 7), "very little has been done to preserve local farmer knowledge or support the farm families that have depended on the tequila industry for generations."

\section{Distilled Agave Producers in Jalisco}

Technological advancements and a growth in the export market triggered significant changes in the systems of production for artisanal tequila and mezcal manufacturers. Such changes prompted the development of a new industry, one based on the excessive production of blue agave (Agave tequilana Weber). Some distilled blue agave manufacturers have replicated the larger industrial model utilized by tequila companies, but on a smaller scale of production and output. Oftentimes, and unlike large tequila 
companies, these products are more likely to incorporate artisanal aspects of production (e.g. handmade bottles, factory design, indigenous implements). Because they are unregulated, it is difficult to accurately determine whether or not they are producing a truly traditional product.

In order to define the groups of producers in this analysis, we categorized agave distillers using the terminology "legal" or "illegal" based on their use of any species of genus Agave L. in the production of distilled alcohol that had an alcohol content of more than $38 \%$ alcohol volume.

12 Having described this set, we can now define the various groups according to three branches which include :

- Tequila industrialists (T): The most industrialized group whose products have a Denomination of Origin. (Photo 1)

- Traditional mezcal manufacturers (TM) : A heterogeneous group with local and historical ties to the region. (Photo 2)

- Modern agave distillers (MA) : A group that emerged as a result of excessive blue agave production that took place on small-scale plantations during the beginning of the 21st century.

Photo 1. Industrial monoculture plantation of blue agave (Agave tequilana), Autlán, Jalisco.

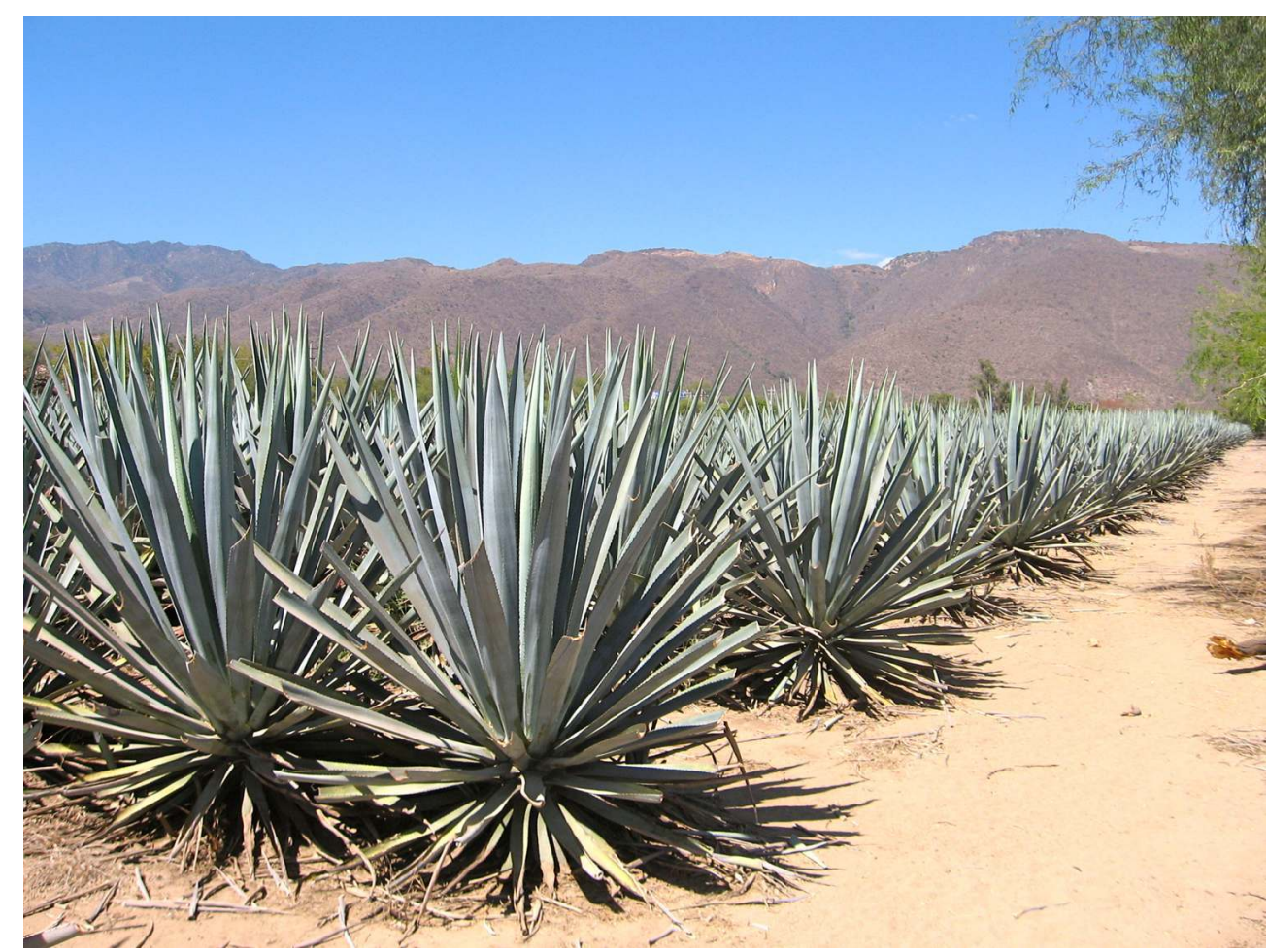

(c)Ana G. Valenzuela Zapata 
Photo 2. Agave maximiliana harvest in Tapalpa, Jalisco in the Barranca tradition.

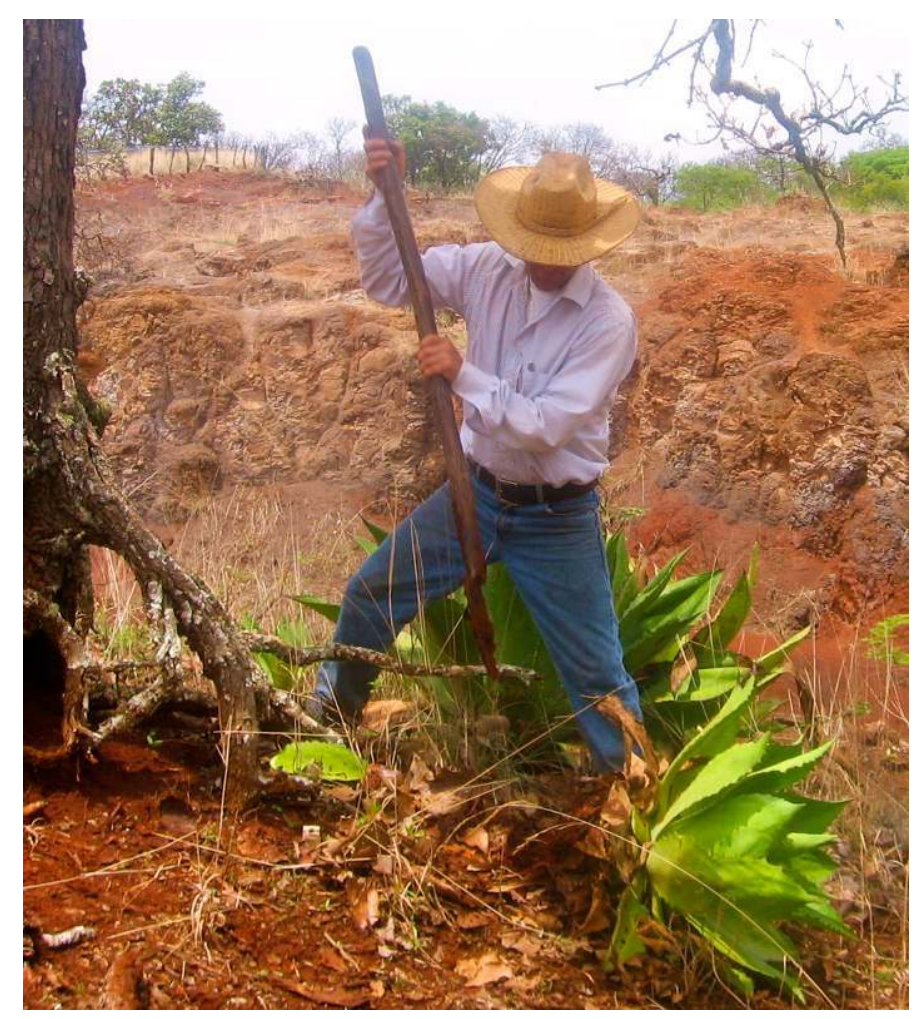

CANA G. VAlenzUELA ZAPATA

\section{Tequila Industrialists}

13 The first significant technological modifications in tequila production took place in the nineteenth century with the introduction of brick ovens and Spanish-style copper stills (Bruman 2000). Other changes emerged in the second half of the twentieth century with the intensified use of monocultural plantations (although not exclusively). In addition, producers began cooking agave in autoclave ovens and started relying on distillation towers that used filters and distilled water mixed with non-agave sugars.

14 In the 1970s, large-scale tequila producers applied pressure on the Tequila Regulatory Council to ensure that only blue agave was added to the mandatory standards of production. As a result of this effort, tequila can only be made with blue agave, even though historically it was produced with a variety of agave (Valenzuela-Zapata and Nabhan 2004). Pro-industrial shifts in production have led to the near extinction of local types of tequila agave landraces such as "pata de mula," "criollo," "sigüín," "moraleño," "bermejo," "chato" or "sahuayo" (Valenzuela 1994).

During the agave crisis (1999-2003), the use of diffusers, (enzymatic hydrolysis and/or uncooked agave acid), which are permitted in the DO, were implemented more frequently. Further, in response to the agave shortage of this period, some of the biggest companies began establishing massive plantations that relied on plant tissue cultures and clonal selection that had low genetic variability. 
Figure 1. Total production of $100 \%$ agave tequila and tequila mixto (made with a minimum of $51 \%$ agave), $1998-2010$ (Millions of liters at $40^{\circ}$ )

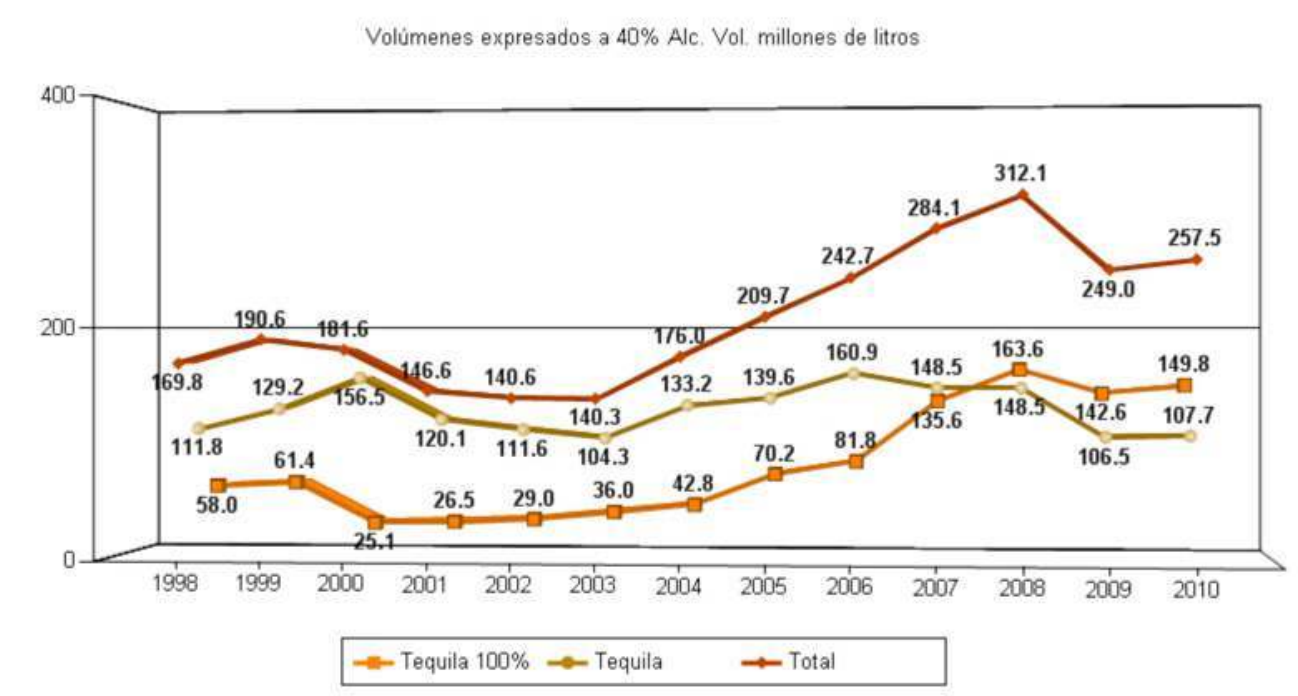

SOURCE : CRT (2011)

In an effort to resist the modern methods used by many contemporary tequila producers, in 1996 Rosa Pla Ma studied a factory in the town José Maria (in the Los Altos region of Jalisco). The distillery ("La Alteña") used a brick oven, wooden barrels for fermentation, and copper stills for distillation. Named "El Tapatío," this brand follows what scholars such as Goddard (1998) describe as an artisanal process that differs from typical industrialized tequilas, especially with regard to flavor and aroma.

\section{Traditional Mezcal Producers and Modern Distilled Agave Producers}

17 Traditional mezcal production generally takes place in “illegal," family-operated factories with between 10 to 50 employees. These production units are described as "illegal" because the manufacturers have not registered their products with the Mexican government. We categorize these operations as a semi-industrialized group of mezcal producers. Mezcal products from Tonaya (legally produced), Tuxcacuesco, and Apulco are trademarked, but cannot legally use the name "mezcal" because they are not within the Denomination of Origin territory for mezcal. (Photos 3-4) 
Photo 3. Cooking mezcal in a brick oven in Tonaya, Jalisco

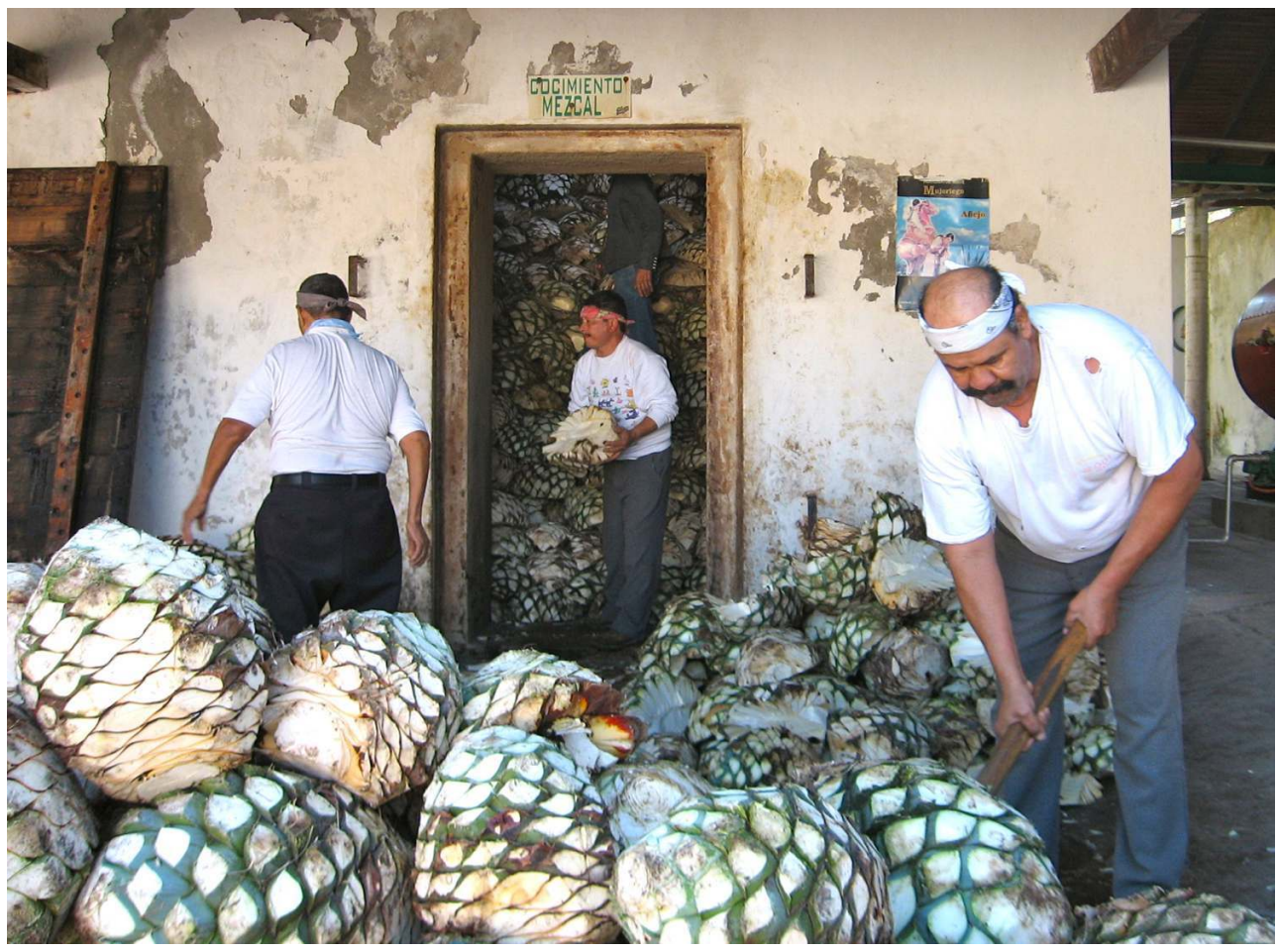

(c)Ana G. Valenzuela Zapata

Photo 4. Day laborer applying pesticides to mixed crops of blue agave $A$. tequilana and lineño $A$. angustifolia in Tonaya, Jalisco

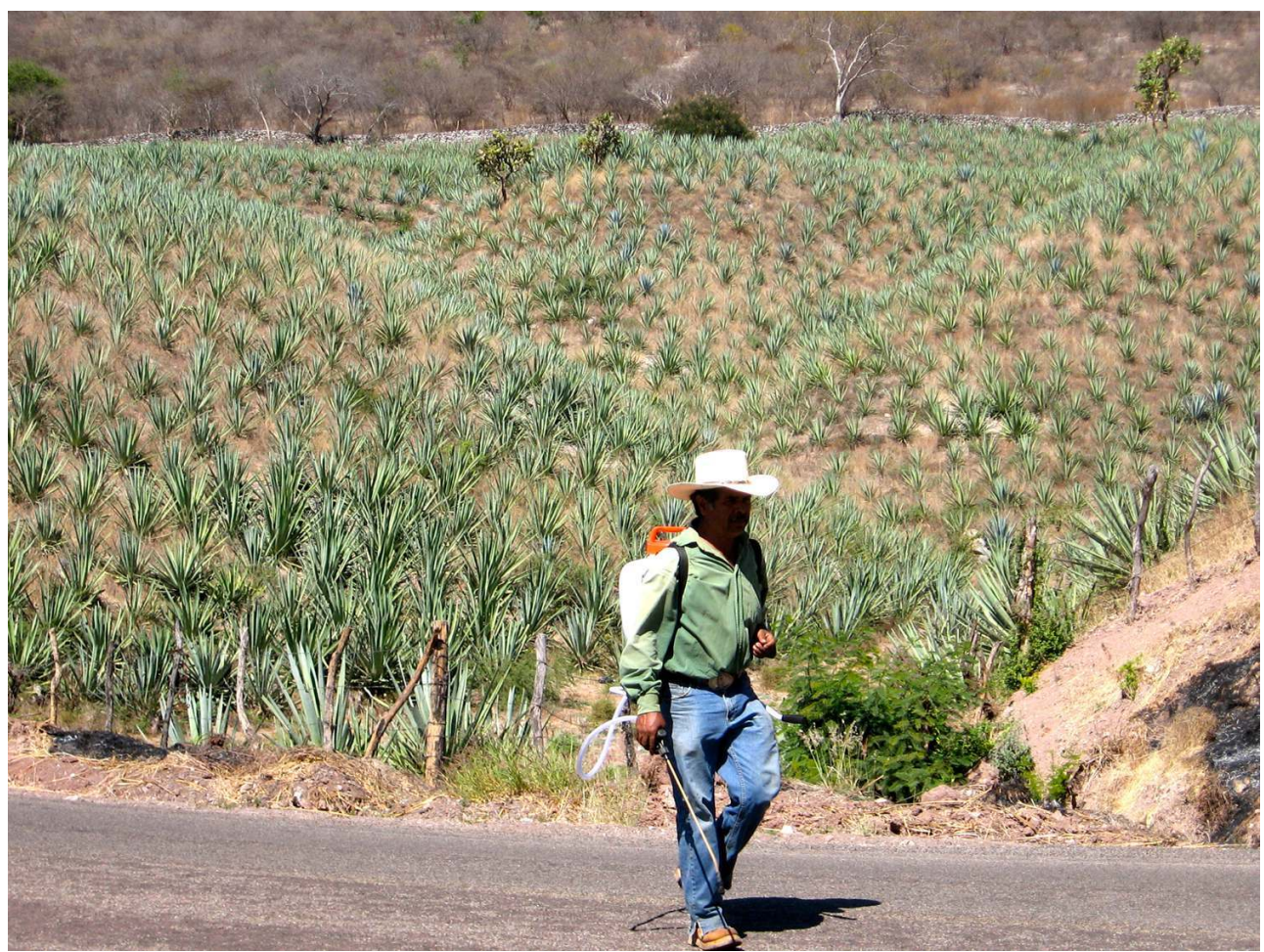

CANA G. VALENZUELA ZAPATA 
We also include raicilla producers in this group, who, since 2000, are also recognized for their own trademark (Marca Colectiva) and distinct traditions (e.g. El Tuito raicilla from a town near Cabo Corrientes and Mascota) (Valenzuela et al. 2008). (Photo 5)

Photo 5. Agave inaequidens crop grown from seeds for Raicilla, in Mascota, Jalisco

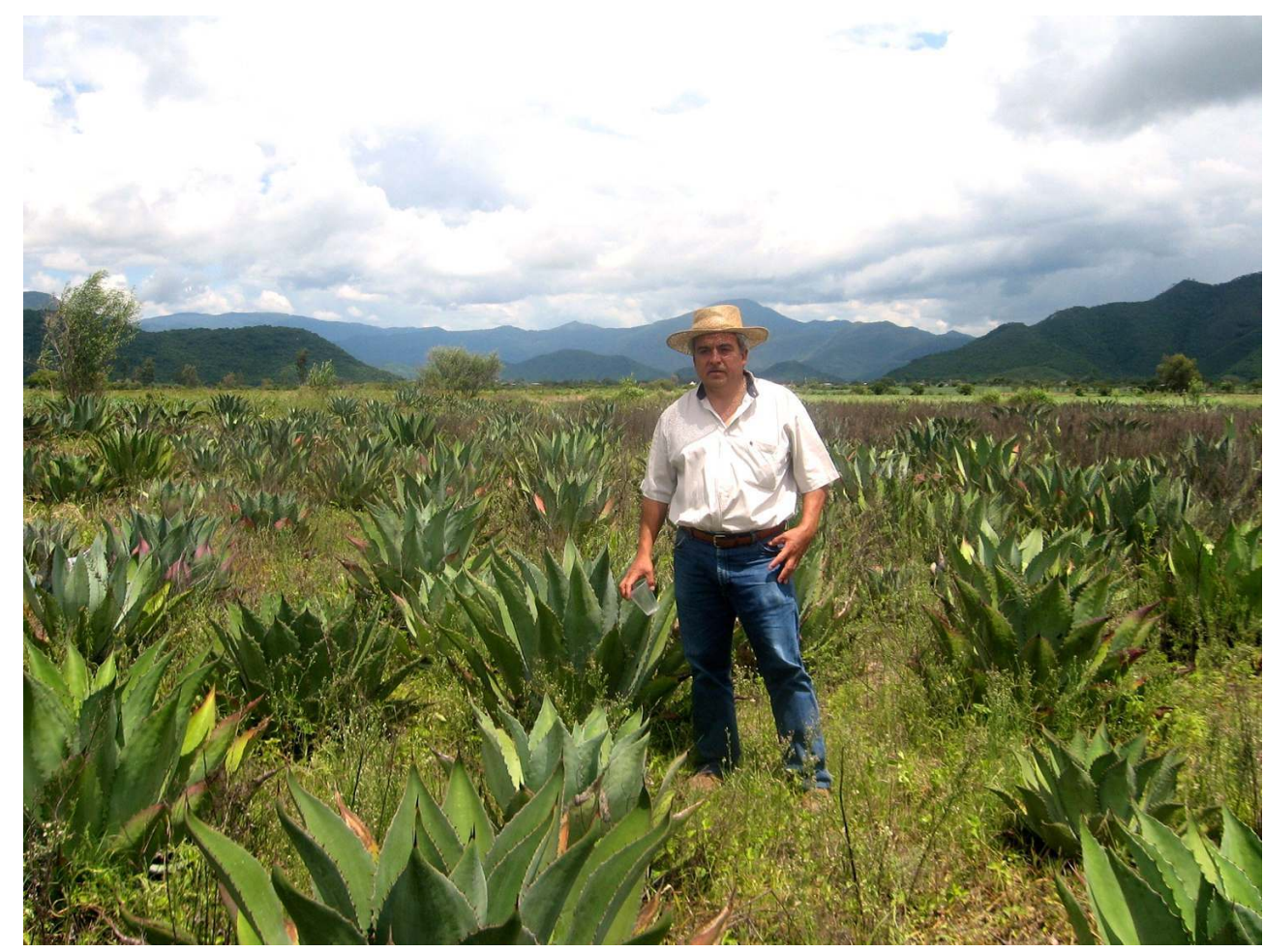

CANA G. VALENZUELA ZAPATA

Finally, we include micro-regional mezcal products, which are generally unnamed, from Zapotitlan de Vadillo (MZV), in addition to Mezcal de Olla from Quitupan, Mazamitla, and Concepcion de Buenos Aires (MO) (Photo 6) and mezcal from Barranca (MB) in Tapalpa and Jalpa. (Photo 7) 
Photo 6. Asian still for mezcal de olla in Mazamitla, Jalisco

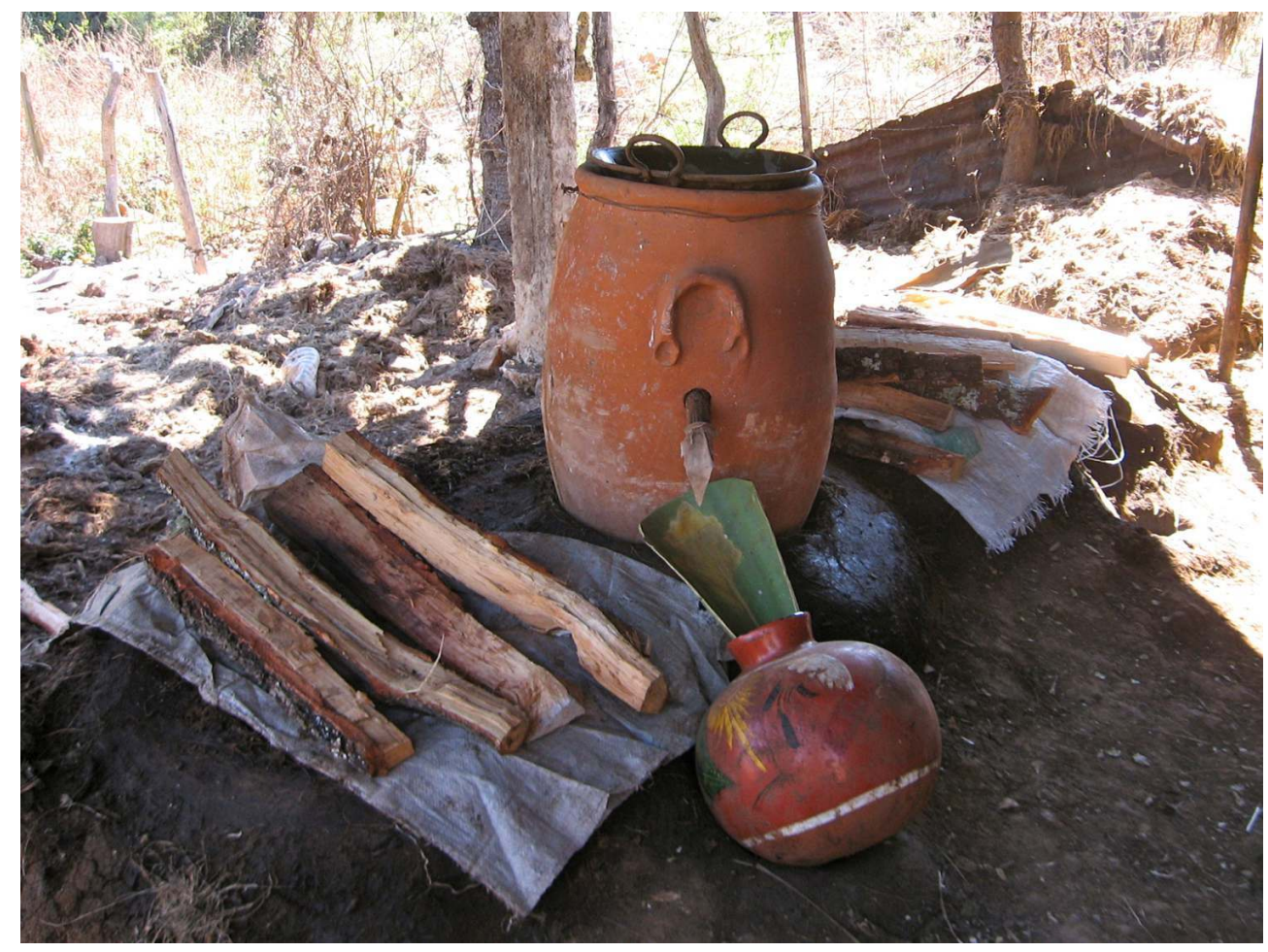

(c)Ana G. Valenzuela Zapata

Photo 7. Fermenting the sugars and bagasse ${ }^{2}$ according to the Barranca mezcal tradition, Chiquilistlán, Jalisco

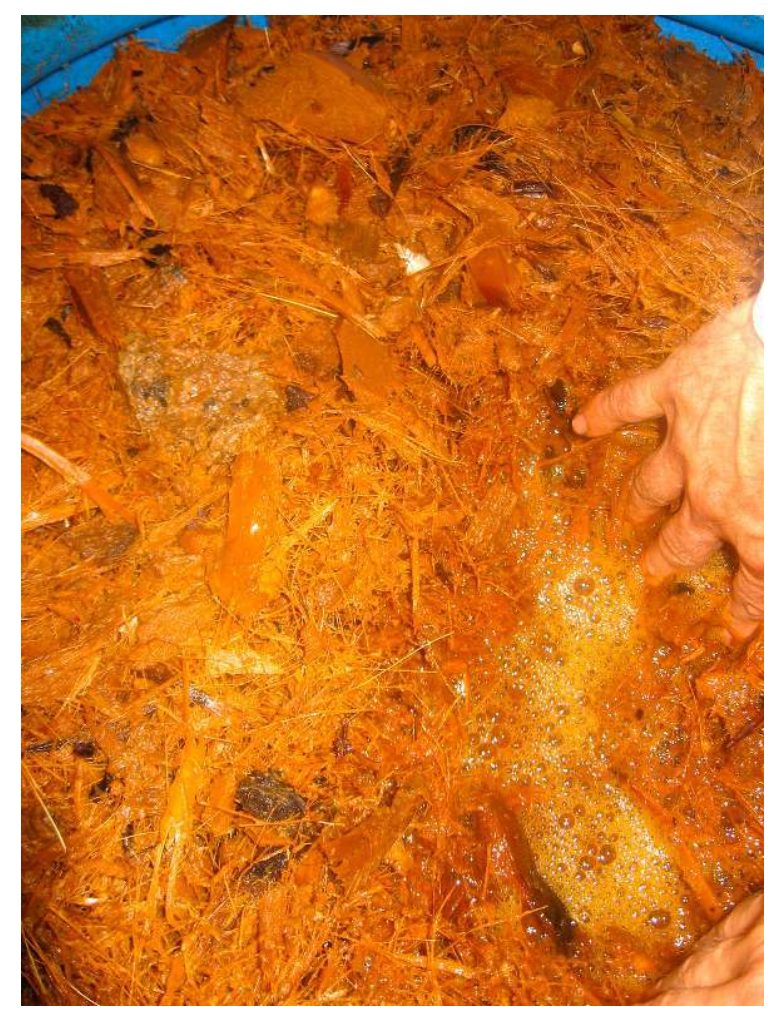

CANA G. VALENZUELA ZAPATA 
The following schema illustrates the framework of distilled agave spirits in Jalisco (Fig 3).

Figure 2. Tequila, Raicilla de Jalisco, and Distilled agave spirits in Jalisco

\section{AGAVE SPIRITS IN JALISCO}

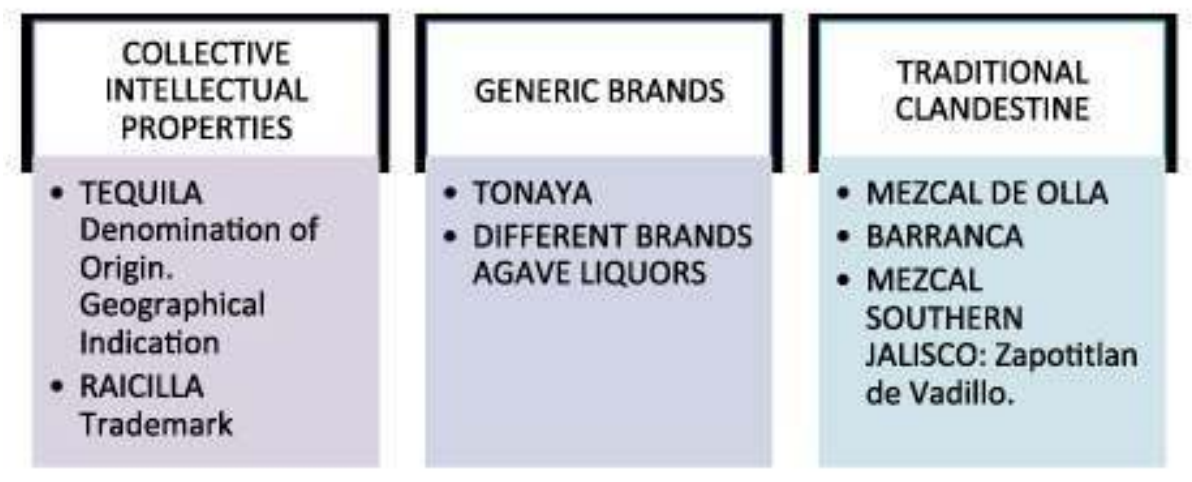

In Table 1 we classify and present the biodiversity of agaves used in the production of distilled agave drinks based on our interview data. Below, we identify four groups of producers : 1) Tequila producers, 2) Mezcal industrialists, 3) Mezcal craftsmen, and 4) Blue agave distillers. Our findings on Mezcal traditions and Agave biodiversity transition trends are compared in Table 1.

Table 1 The production characteristics, processes implemented, and the agave species used in each product. (Below)

\begin{tabular}{|c|l|l|}
\hline & Product/Municipality & Activities and dates \\
\hline 1 & Mezcal/ Zapotitlan de Vadillo & Distillery interview and field visit 06/2006 \\
\hline 2 & Tequila Espolon/Arandas & Distillery interview 06/2006 \\
\hline 3 & Tequila Cuervo/Tequila & Distillery interview 11/2006 \\
\hline 4 & Raicilla El Tuito/Cabo Corrientes & Field visit $11 / 2007$ \\
\hline 5 & Raicilla/ Mascota & Distillery interview 13-22/01/2008 \\
\hline 6 & Mezcal/ Tonaya & Interview distillery and field visit 02/2008 \\
\hline 7 & Destilados de agave/Autlán & Interview distillery and field visit 02/2008 \\
\hline 8 & Mezcal de Olla/Mazamitla & Distillery interview 02/2008 \\
\hline 9 & Barranca Tapalpa/Tapalpa & Distillery interview and field visit 03/2008 \\
\hline 10 & Tequila El Mayoral/ Jesus Maria & Distillery interview 04/2008 \\
\hline 11 & Raicilla El Tuito-El Cono/Cabo Corrientes & Distillery interview and field visit 05/2008 \\
\hline 12 & Barranca Jalpa/Chiquilistlán & Distillery interview and field visit 06/ 2008 \\
\hline 13 & Raicilla Mascota/Mascota & $\begin{array}{l}\text { Focus group producers, field visits, } 2 \text { distil- } \\
\text { lery interviews: Traditional and new distillery } \\
\text { 07/2008 }\end{array}$ \\
\hline & &
\end{tabular}




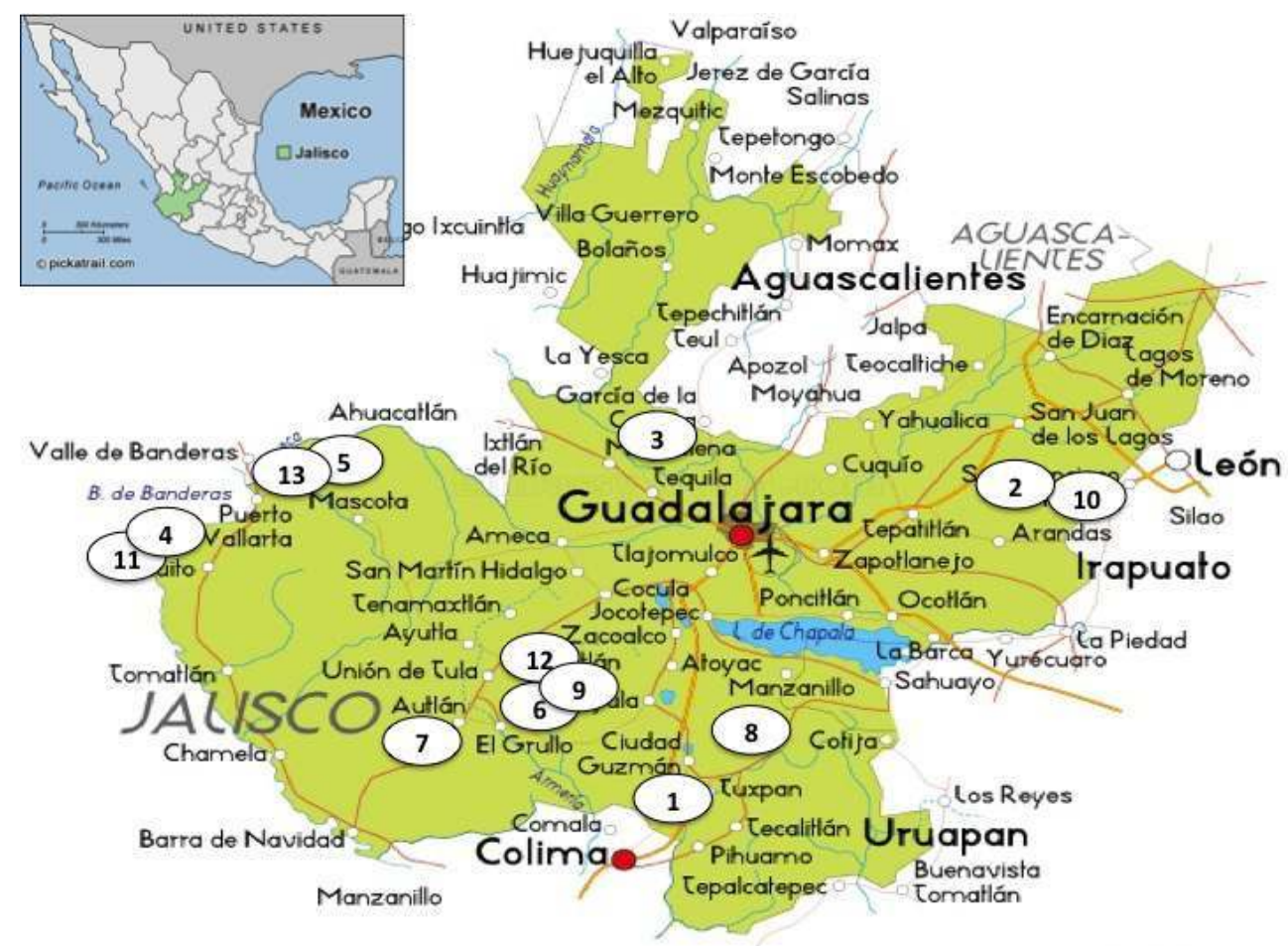

In recent years, mezcal producers have started to modernize their operations in an effort to become legitimate business establishments (Gutiérrez-Coronado et. al. 2007). Paradoxically, the pressure for formal recognition works against efforts to preserve traditional methods of mezcal production (Bowen and Gaytán 2012). The value of safeguarding traditional knowledge has not been adequately addressed by the Mexican Institute of Intellectual Property or the Ministry of Economy. Consequently, biodiversity is compromised and indigenous techniques are de-legitimized.

\section{Mezcal Traditions in Jalisco}

Although scholars have paid much attention to modern methods of mezcal production, few have adequately addressed the local savoir-faire of indigenous manufacturers in Jalisco. (It should be noted that in Jalisco's rural settlements, where there is a greater tradition in the use of agave, the word "mezcal" is preferred over "maguey", used in central and southern Mexico.)

In the region of Sierra de Amula in Jalisco, Luis Fabian (2004: 53) recorded a conversation with a Nahua mezcal maker from Tuxpan ${ }^{3}$, who described the handmade process, now mostly disappeared in that area :

"...and I chopped in underneath with a wide coa $^{4}$; carried the mezcal on donkeys and then I threw it in a deep well, more than a body deep, buried in the well... it was tezcal ${ }^{5}$... and there I gave fire and wood to the stone; I made a pile of wood and I gave it fire, and it burned. Then I threw in the stone, and until the wood stops burning then you throw in the mezcal. Then you had to cover it with dry grass (zacate), then with earth. It stayed covered for two days, then you hack it with an ax dripping in sweat. The bagasse turned out really tender, well ground, to throw it into a wide well, like of tezcal with stone, and you had the mud gathered so the juice wouldn't spill. Once you got the juice, it was put in dishes where the bagasse fermented; and from that you get pure wine, son of a morn! So strong is the bagasse. Then I threw it into an earth oven, and there's a pot underneath and over 
it a montera ${ }^{6}$, that's also a pot; and in the pot an earth spoon and the wine comes out from here... a small stream... it's the late wine. You fill the jars and the wine is, son of a morn! tasty! It's a good wine, special. Nowadays they don't know how to obtain the wine. That was my job".

Tuxpan was an important site for mezcal production, even though most of the products were clandestinely manufactured, and hence considered "illegal." Different agave species also thrived there. At one time, "There was mezcal in every pasture. There isn't any more because there are too many rats" (2004: 54$)$.

\section{The Artisanal Production Process in Jalisco}

Based on interview data and participant observation, below, we summarize the handmade process employed by traditional producers to make mezcal from $100 \%$ agave.

Seasonal and intermittent production, close to streams or rivers. Handmade process includes : 1) Harvesting or gathering of diverse species, mixed race, and ecotypes of wild agave; 2) Cooking of the agave in stone underground ovens, bread ovens, and/or masonry slow cooking ovens; 3 ) Grinding of the cooked agave (mezcal) in hollow logs, in stone vats, in tahonas or stone mills and even manual and/or mechanical mills; 4) Fermenting with or without bagasse, with or without water, but always with native yeasts; 5) Distilling in Asian-influenced equipment and/or copper and partially stainless steel stills; 6) Standing of the non-diluted distilled liquid in glass containers.

In order to ensure the optimum aromatic profile, mezcal production requires the following elements to be in place : a slow cooking process, spring or mountain stream water, yeasts common to cooked ground agave musts, and distillation with speciallyadapted small-scale production equipment.

\section{Agave Biodiversity Transition}

\section{Raicillas and the Agave Selection Process}

Raicillas are a special case in Jalisco's mezcal tradition because they require the use of several species and agave cultivars. Raicilla made in the traditional ovens of El Tuito (TR = Tuito Raicilla) combines the creole breeds A. angustifolia and A. rhodacantha of thin and stiff leaves (see picture 1), and in Mascota (MR Mascota Raicilla ) the A. inaequidens, A. maximiliana y A. valenciana with natural wild dispersed seeds and also those from nurseries (see picture 2).

ual reproduction plantations are used for TR, such as those used for tequila ( $A$ tequilana blue var.), in Oaxaca (A. angustifolia espadin var.) and in Tonaya (A. angustifolia, lineño var.). At the same time, production of MR requires a wild population that reproduces exclusively by seed, as with papalometl ${ }^{7}$ mezcal from Oaxaca (A. potatorum Zuccarini) and Chilapan ${ }^{8}$ mezcal from Guerrero (A. cupreata Trelease and Berger).

We discuss these plants' reproductive biology in order to emphasize the differences in the traditional knowledge, degrees of exploitation, and production systems for raicillas. It is also worth noting that mixed or local varieties from phytogenetics "are an early form of farming developed from a wild population, and composed, generally, by a heterogeneous mix of genotypes" (FAO, 2004). Therefore, raicilleros (raicilla producers) in Mascota collect three species with a high intra-specific variation, whereas at El Tuito they use local 
cultivars which have been domesticated from two species, A. angustifolia and A. rhodacantha with a rich infra-specific diversity (Valenzuela et. al 2009). One way of compromising diversity in domesticated plants as local varieties is to stop planting them -a process that takes place because they only reproduce asexually, and some of them have few seeds and low germination levels.

Raicilleros from Mascota depend on wild agave for re-collection, which is adversely affected by factors such as wildfires, climate disasters, over-grazing, and changes in the use of the land. Nevertheless, raicilleros have organized themselves in order to harvest plantations, improve their taverns, and register their brands. Under these structured conditions, raicilleros are better able to better balance the disadvantages that result from an overall insecurity in the supply of agave.

Agaves' reproductive biology, production systems, and agro-ecosystems also influence traditional knowledge. Raicilleros from El Tuito directly manage the genetic resources of agaves in relation to plantation agriculture, whereas raicilleros from Mascota focus on the extraction of non-timber forest products. The difference between being an agave farmer or someone who is contracted to harvest agave also defines the type of producers, organizations, and strategies to introduce technological innovations for the sustainable use of resources. In other words, from a sustainable management perspective, improvement projects would have to consider the unique characteristics of each species, along with the manner of their domestication and reproduction.

\section{Threats to Biological Diversity}

34 Jaliscan mezcal retains close ties to traditional methods of production; however, it is no stranger to the unstable price of agave or the evolution of artisanal products into agrobusinesses. The process of analyzing the combined effects of organizations, migration, and political management of producer networks is complex. Today there is growing pressure among small-scale producers to modernize and integrate products into domestic and international markets. Yet, as our interviews indicate, small scale artisan producers and the owners of family-operated businesses show little interest in entering new markets, or relinquishing their traditional equipment for modern technologies. Instead, they see the adoption of new measures as negatively affecting the taste and quality of their home-made products.

Conversely, medium-sized producers, who have adopted new technologies on a smaller scale of production, are more willing to continue production without legally naming their products "mezcal." In doing so, they are able to use bi-varietal agaves (blue agave and lineño agave) in their products. According to studies by Vargas, et al. $(2007,2009)$, as well as those by Valenzuela-Zapata et al. (2008), mezcal and raicilla producers in Southern Jalisco (Zapotitlan de Vadillo), who used the largest number of species and cultivars with regard to collection and cultivation, are also not immune to threats to biodiversity.

The long-standing practice of mixing different agave species, and the close observation of mature agave selection, are vital factors in the conservation of biodiversity. Therefore, it is important to note that the introduction of technical support to rural mezcal production in Jalisco can be a double-edged sword, especially when reports by technicians recommend new technologies for production "improvements." In their calls for "improvements," technicians often suggest that producers abandon their equipment, utensils, and even disregard their traditional knowledge. These technicians interpret the 
continued use of traditional methods as both inefficient and "backward." As a result, the knowledge of small-scale producers is consistently devalued. Yet, many of these local producers resist the recommendations made by technicians. For example, in the case of raicilla producers affiliated with the Mexican Council of Raicilla Promotion, 25 to 30 per cent are reluctant to make changes or modernize their production methods (Personal communication with Dr. Isaac Andrade González, a noted raicilla researcher, January, 2010). Importantly, not all producers reject the use of modern technologies-many do not have the financial resources to adopt new measures of production.

With respect to changes in biodiversity, there is a risk that local varieties will disappear due to selection pressure exerted by using two varieties of A. angustifolia in El Tuito. These production systems do not resemble the production systems of tequila, especially with regard to inputs, machinery, and monoculture. Producers in El Tuito emphasize that they are not interested in making any changes to the types of agave they use. As they explained, blue agave required too much upkeep to harvest in comparison to other types of native agave.

By looking at the growth trends for Oaxaca's mezcal industry and Jalisco's tequila industry, we can extrapolate that agaves grown from seed, like those of the Western Sierra Madre, would be difficult to integrate into an industrial setting and thus will likely remain artisanal products. Raicilla from El Tuito and Mascota are two products known for their taste and quality; they have solid reputations in retail outlets, but also through word of mouth, as "authentic" raicilla craftsmen.

\section{Geographical Indications and Biodiversity Protection}

Mezcal is the generic name for different distilled agave drinks made in Mexico for more than five centuries. Although tequila is a type of mezcal that is protected under DO regulations, most tequila companies rely on highly technical systems of production that focus on output and not on biological or cultural diversity. Similar to the discussion by Larson et al. (2007), we highlight the limitations associated with adopting this type of strategy. In particular, we contend that the traditions, and the diverse agave species associated with the manufacture of artisanal mezcal, are endangered.

Globally, Geographical Indications are a wide-ranging set of national and international intellectual property systems for regulating commerce. The only feature that they share in common is the use of toponyms, otherwise each GI is administered differently, and it is not, therefore, a synchronized system. As the above findings illustrate, despite the intent of GIs, to serve as legislative tools that protect cultural products and promote sustainable and rural development, they are unsuccessful at achieving these objectives for several reasons. First, GI guidelines vary across nations, and thus yield inconsistencies. Secondly, they do not outline specific conservation processes or consider species diversity, as the case of mezcal production in Jalisco illustrates. In contemporary Mexico, the GI system remains unregulated (Valenzuela and Macias forthcoming).

There are two distinguishing systems regarding collective intellectual property: Denominations of Origin and trademarks. Mexican DOs are classified as GIs, in part, due to Mexico joining the World Trade Organization. Although Mexican DOs were based on a European framework (via the Lisbon Agreement), they have since been adapted to meet the demands of a market-oriented dynamic-one driven by the increased consumption of tequila in the United States. Far from Europe, and entangled with the market demands of 
and policy ties with the United States (e.g. the implementation of NAFTA in 1994), Mexican DOs have been modified to meet strict production standards, with no consideration of agave species conservation or artisanal savoir-faire. In other words, there are no limits on the use of technology, nor are there distinctions made between artisanally and industrially-produced types of tequila (or mezcal). Characterized by threefold growth in the last twenty years, tequila industry norms support massproduction technologies at the expense of biological and cultural diversity.

In this article, we focus specifically on the case of traditional mezcal manufactured in Jalisco. Although mezcal is made principally in Guerrero, Oaxaca, San Luis Potosí, Tamaulipas, and Zacatecas, producers in these states draw on their own unique regional customs in relation to their methods of production. Therefore, it is vital that researchers study and classify both the traditional knowledge and biodiversity associated with these products before pressures from Mexican DO regulations render them obsolete.

\section{Conclusions}

Drawing on the lesser-known aspects of artisanal mezcal production in Jalisco, Mexico, this article sheds important light on issues of biodiversity and traditional knowledge. Traditional mezcal production has been affected by the dramatic growth of the tequila industry. From 2000 to 2010, raicilla and other mezcal producers in Jalisco incorporated blue agave in their products because of its surplus and its low price ( $\$ 1.00$ per kilogram). Indeed, many industry insiders have dubbed the over-cultivation of blue agave as "agavización" (agavization). As a result of over-cultivation, natural populations of agave have been re-stocked and crop development has been re-invigorated. Thus, when the price of agave reached historical levels (between 1999 and 2003), agaves harvested from different species contributed to the "other sugars" category of tequila production.

During periods of blue agave scarcity, large-scale producers illegally use mezcal and raicilla agaves for the manufacture of tequila (Author interview, 2008). Any change in the price of blue agave severely impacts the mezcal regions of Jalisco and other states like Oaxaca and San Luis Potosí. With a reported 253 million agave plants in the current inventory (CRT 2011), it is very likely that we are on the brink of a new shortage (and crisis) of blue agave. If this is the case, then traditional mezcal producers will face serious threats in the near future.

Traditional tequila production ${ }^{9}$ is practically extinct because not enough has been done to preserve collective knowledge, ensure certification, or establish legal and commercial distinctions among the differing production methods. Today the Tequila-Amatitán region is portrayed by UNESCO as "natural" landscape filled with blue agave. Ironically, however, the monocultural fields of blue agave are modern installations, established in the middle of the twentieth century. The UNESCO evocation of "heritage" is based on a contemporary, "invented" idea of what counts as tradition that falsely evokes notions of the "past." Starting in the $20^{\text {th }}$ century, many agaves, and many distilled agave beverages, have disappeared from local municipalities. Therefore, we maintain that Geographical Indications such as tequila and mezcal are severely limited in their ability to promote biodiversity conservation within Mexico. This is an urgent issue that requires more research by scholars of various disciplines interested in preserving the cultural and natural heritage of Jalisco. 
We would like to thank the mezcal producers who agreed to be interviewed, the anonymous reviewers, Gabriel Santos Navarro, and Gwyn Fisher for their assistance with this article. We would also like to thank researchers from the Instituto Tecnológico Tlajomulco for their insight regarding the evolution of modern raicilla production.

\section{BIBLIOGRAPHIE}

Blomberg L. 2000 - Tequila, Mezcal, y Pulque : Lo Auténtico Mexicano. Mexico, Editorial Diana, 314 p. Bowen S. \& Gaytán M.S. 2012 - The Paradox of Protection : National Identity Global Commodity Chains, and the Tequila Industry. Social Problems, 59(1) : 70-93.

Bowen S. \& Valenzuela-Zapata A.G. 2009 - Geographical Indications, Terroir and Socioeconomic and Ecological Sustainability : The Case of Tequila. Journal of Rural Studies, 25(1) : 108-119.

Bruman H.J. 2000 - Alcohol in Ancient México. Salt Lake City, University of Utah Press, 158 p.

Colunga García-Marín P. \& Zizumbo-Villarreal D. 2007 - Tequila and Other Agave Spirits from West-Central Mexico : Current Germplasm Diversity, Conservation and Origin. Plant Biodiversity and Conservation, 16(6): 1653-1667.

Colunga García-Marín P., Zizumbo-Villarreal D. \& Martinez-Torres J. 2007 - Tradiciones en el aprovechamiento de los agaves mexicanos : una aportación a la protección legal y conservación de su diversidad biológica y cultural. In Colunga García-Marín P., Larqué-Saavedra A., Eguiarte L.A., Larqué S. \& Zizumbo-Villarreal D. (Ed.), En lo ancestral hay futuro : del tequila, los mezcales y otros agaves. Mérida, Yuc., CICY-CONACYT-CONABIO-INE, 402 : 229-248.

Consejo Regulador del Tequila 2011 - Estadísticas. Producción de Tequila. www.crt.org.mx. January 7, 2012.

Fabian L. 2004 - En recuerdo del mezcal. In Ramírez H. X. \& Amador E. (Ed.) Conversaciones con indígenas de Tuxpan. Guadalajara, Jalisco, México, Ed. Largatija Azul : 53-54.

FAO 2004 - Glosario de biotecnología para la agricultura y la alimentación. (http://www.fao.org/ docrep/004/y2775s/y2775s00.htm\#Contents)

García-Mendoza A. 2002 - Distribution of genus Agave (Agavaceae) and its endemic species in Mexico. Cactus and Succulent Journal, 74 : 174-187.

Gaytán M.S. 2008 - Fermented Struggles and Distilled Identities : Tequila and the Making of a National Spirit. Unpublished dissertation. Santa Cruz, University of California.

Gentry H.S. 1982 - Agaves of Continental North America. Tucson, University of Arizona Press, 670 p.

Larson J., Valenzuela-Zapata A.G. \& Illsley C. 2007 - Del whisky escocés al mezcal : diferenciación y etiquetado, desarrollo y conservación. In Colunga García-Marín P., Eguiarte L.A., Larqué S. y Zizumbo-Villarreal D. (Ed.). En lo ancestral hay futuro : del tequila, los mezcales y otros agaves. México, CICY-CONACYT-CONABIO-INE : 213-228. 
Luna R. 2005 - Disyuntivas del patrimonio del tequila en la era neoliberal. In Contreras Delgado C. \& Ortega Ridaura I. (Ed.), Bebidas y regiones : Historia e impacto de la cultura etílica en México. México D.F., Plaza y Valdés, S. A. de C.V. : 21-38.

Secretaría de Economía 2006a - Norma Oficial Mexicana NOM-006-SCFI-2005, Bebidas alcohólicasTequila-Especificaciones, Diario Oficial de la Federación, 6 de enero de 2006.

Secretaría de Economía 2006b - Norma Oficial Mexicana de Emergencia NOM-EM-012-SCFI-2006. Diario Oficial de la Federación, 30 de noviembre de 2006.

Secretaría de Economía 2009 - Norma Oficial Mexicana NOM-070- SCFI-1994. Bebidas AlcohólicasMezcal-Especificaciones, Diario Oficial de la Federación, 5 de agosto de 2009.

Valenzuela-Zapata A.G. 1994 - Los Agaves Tequileros. Boletín Amaranto, 7(3) : 1-8.

Valenzuela-Zapata A.G. 2003 - El agave tequilero. Cultivo e industria de México. México, Ed.

Mundiprensa, $215 \mathrm{p}$.

Valenzuela-Zapata A.G. 2011 - A New Agenda for Blue Agave Landraces : Food, Energy and Tequila. Bioenergy, 3(1) : 15-24.

Valenzuela-Zapata A.G. \& Nabhan G.P. 2004 - Tequila! A Natural and Cultural History. Tucson, University of Arizona Press, 113 p.

Valenzuela-Zapata A.G., Regalado A. \& Mizoguchi M. 2008 - Influencia asiática en la producción de mezcal en la costa de Jalisco. El caso de la raicilla. México y la Cuenca del Pacífico 11(32) : 81-116.

Valenzuela-Zapata A.G. \& Macias Macias A., [forthcoming] - Tequila : Lecciones de la primera Denominación de Origen Mexicana. CONABIO-MUNDIPRENSA Eds.

Vargas-Ponce O., Zizumbo-Villarreal D. \& Colunga García-Marín P. 2007 - In situ Diversity and Maintenance of Traditional Agave Landraces Used in Spirits Production in West-Central Mexico. Economic Botany 61(4) : 362-375.

Vargas-Ponce O., Zizumbo-Villarreal D., Martínez-Castillo J., Coelho Coelho J. \& Colunga GarcíaMarín P. 2009 - Diversity and structure of landraces of agave grown for spirits under traditional agriculture : a comparison with wild populations of Agave angustifolia (Agavaceae) and commercial plantations of A. tequilana. American Journal of Botany, 96(2) : 448-457.

Zizumbo-Villareal D. \& Colunga García-Marín P. 2008 - Early coconut distillation and the origins of mezcal and tequila spirits in west-central Mexico. Genetic Resources and Crop Evolution, 55(4) : 493-510.

Zizumbo-Villarreal D., González-Zozaya F., Olay-Barrientos A., Almendros-López L., Flores-Pérez P. \& Colunga García-Marín P. 2009 - Distillation in Western Mesoamerica Before European Contact. Economic Botany, 63(4) : 413-426.

\section{NOTES}

1. Pedro de Tagle founded one of the largest haciendas near Tequila and is said to have initiated the large scale production of vino mezcal de Tequila. Today, academics colloquially refer to him as the "father of tequila" (Blomberg $2000: 6$ ).

2. Bagasse is a French word that denotes the remnants of the sugar cane stems from which juice is extracted. Here it is applied to the cooked piña of the agave. It is possible that this word dates from the French occupation of Mexico, 1862-1867. 
3. Perhaps Tuxpan mezcal was sold in Tuxcacuesco and named as "Tuxca"-- a mezcal tradition that is likely extinct; however, more research is needed to substantiate this claim.

4. Coas : there are 2 types of coas : one is circular, used for harvesting and the other is triangletrapezoidal, used for removing weeds) (Valenzuela 1994).

5. Tezcal refers to a type of rock used to make ovens.

6. Montera refers to the upper part of the (Asian-style) still which functions as a condenser. It is usually a metal case filled with water, built into the body of the boiler. To keep the water cool inside the condenser, the case has tubes going in and out through which water flows.

7. Papalometl is the Nahuatl term for maguey mariposa, which refers the butterfly form of agave leaves.

8. Chilapan is the name of a village in Guerrero.

9. A small number of modern tequila producers use traditional elements such as brick ovens, wood containers for fermentation, bagasse fermentation, and a tahona -a stone wheel used to mash cooked agave.

\section{RÉSUMÉS}

La notion d'Indication Géographique (IG) exposée par l'Organisation mondiale du commerce, identifie les lignes directrices spécifiques de qualité et protège les aliments, boissons et autres produits de la concurrence, en fonction de leur origine géographique ou lieu spécifique. Au Mexique, les IG sont connues comme Dénominations d'Origine (DO), et en 1974, la téquila a été reconnue comme le premier produit mexicain de DO. En 1994, le gouvernement mexicain a créé une DO pour la catégorie des boissons d'agave distillé, le mezcal. Dans l'État de Jalisco, au Mexique, il existe plusieurs types de mezcal, mais quelques-uns seulement sont reconnus sous la réglementation DO. Bien que fabriqués artisanalement dans le Jalisco depuis des siècles, de nombreux mezcals, comme la raicilla, ne sont pas protégés par le système DO. Les fabricants traditionnels, qui sont souvent eux-mêmes cultivateurs d'agaves, jouent un rôle important dans le maintien des ressources écologiques de la région. Nous nous sommes intéressées à trois boissons (téquila, raicilla et mezcal), chacune produite dans le Jalisco, au Mexique, pour étudier comment les différents acteurs sociaux négocient les questions relatives à la biodiversité. En particulier, nous attirons l'attention sur les fabrications artisanales de ces boissons et les traditions humaines qui soutiennent le développement durable. De plus, nous mettons l'accent sur un ensemble d'espèces d'agaves (sauvages et cultivés), utilisés à la fois par des grands producteurs et par d'autres sur de plus petites surfaces, en tenant compte de la diversité des agaves et de leurs efforts pour se maintenir sur le marché des spiritueux. Plus précisément, nous posons les questions suivantes : Quelles sont les espèces d'agaves actuellement utilisées à la fois par les grands et les petits fabricants de téquila et de mezcal dans l'État de Jalisco? Quelles sont les conditions permettant une utilisation plus importante de biodiversité spécifique et variétale indigènes? Comme nous le montrons, les producteurs artisanaux sont plus susceptibles d'utiliser des espèces variées d'agaves dans la fabrication de leurs boissons distillées. Mais les pressions pour moderniser leurs méthodes de production menacent la diversité écologique et culturelle de ces produits du terroir.

Outlined by the World Trade Organization, Geographical Indication (GI) designations identify specific quality guidelines and protect foods, drinks, and other products from competition based 
on their specific geographical origin or location. In Mexico, GIs are known as Denominations of Origin (DO), and in 1974, tequila was recognized as Mexico's first DO product. In 1994, the Mexican government established the DO for the distilled agave drink category, mezcal. Within the western state of Jalisco, Mexico, there are several different types of mezcal, however only a few are classified under DO regulations. Although handcrafted in Jalisco for centuries, many mezcals, like raicilla, are unprotected under the current DO system. Traditional manufacturers, who are often themselves agave farmers, play an important role in the maintenance of the region's ecological resources. Focusing on three drinks (tequila, raicilla, and mezcal), each produced in Jalisco, Mexico, we analyze how various social actors negotiate issues pertaining to biodiversity. In particular, we call attention to artisan craftsmanship and the human traditions that characterize sustainability. Further, we focus on a range of agave species (wild and cultivated), used by both large and small scale producers, in relation to agave diversity and conservation efforts in the distilled spirits market. Specifically, we ask the following questions : What agave species are currently used by both large and small scale manufacturers of tequila and mezcal in the state of Jalisco? What conditions enable the incorporation of more bio-diverse species and native landraces? As we show, artisanal producers are more likely to use diverse species of agave in the manufacture of their distilled drinks. Pressures to modernize their methods of production threaten the ecological and cultural diversity of regional Jaliscan products.

\section{INDEX}

Keywords : mezcal, tequila, traditional knowledge, agave conservation, biodiversity, Geographic Indications, denominations of origin, cultural diversity.

Index géographique : Mexique

Mots-clés : raicilla, savoir traditionnel, agave, biodiversité, indication géographique, appellation d'origine, diversité culturelle

\section{AUTEURS}

\section{ANA G. VALENZUELA ZAPATA}

Universidad de Guadalajara.

Founder, Signo Tequila

www.signotequila.org.

ana.valenzuela@gmail.com

\section{MARIE SARITA GAYTÁN}

Department of Sociology and Gender Studies

University of Utah

sarita.gaytan@soc.utah.edu 